\title{
In Vitro and In Vivo Model Systems for Studying Enteropathogenic Escherichia coli Infections
}

\author{
Robyn J. Law ${ }^{1,2}$, Lihi Gur-Arie ${ }^{3}$, Ilan Rosenshine ${ }^{3}$, and B. Brett Finlay ${ }^{1,2,4}$ \\ ${ }^{1}$ Michael Smith Laboratories, University of British Columbia, Vancouver, British Columbia V6T 1Z4, Canada \\ ${ }^{2}$ Department of Microbiology and Immunology, University of British Columbia, Vancouver, British \\ Columbia V6T 1Z4, Canada \\ ${ }^{3}$ Department of Microbiology and Molecular Genetics, IMRIC, The Hebrew University of Jerusalem, \\ Faculty of Medicine, Jerusalem, Israel \\ ${ }^{4}$ Department of Biochemistry and Molecular Biology, University of British Columbia, Vancouver, \\ British Columbia V6T 1Z4, Canada \\ Correspondence: bfinlay@msl.ubc.ca
}

\begin{abstract}
Enteropathogenic Escherichia coli (EPEC) and enterohemorrhagic E. coli (EHEC) belong to a group of bacteria known as attaching and effacing (A/E) pathogens that cause disease by adhering to the lumenal surfaces of their host's intestinal epithelium. EPEC and EHEC are major causes of infectious diarrhea that result in significant childhood morbidity and mortality worldwide. Recent advances in in vitro and in vivo modeling of these pathogens have contributed to our knowledge of how EPEC and EHEC attach to host cells and subvert hostcell signaling pathways to promote infection and cause disease. A more detailed understanding of how these pathogenic microbes infect their hosts and how the host responds to infection could ultimately lead to new therapeutic strategies to help control these significant enteric pathogens.
\end{abstract}

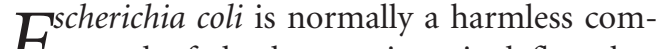

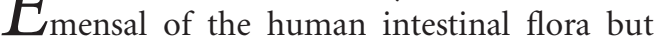
some strains have acquired the ability to cause disease in humans ranging from meningitis to urinary tract infections and diarrhea. Six of the eight well-studied E. coli pathovars are diarrheagenic, and although each pathovar has a distinct mechanism of disease, many virulence strategies are shared between them (Croxen and Finlay 2010). Enteropathogenic E. coli (EPEC) is a leading cause of watery and potentially fatal diarrhea in infants that is often accompanied by vomiting, fever, and dehydration (Nataro and
Kaper 1998; Kaper et al. 2004; Croxen and Finlay 2010). EPEC poses a substantial health concern mainly for children in developing countries (Kaper et al. 2004) but has also been linked to sporadic cases in daycare facilities in North America and Europe (Nataro and Kaper 1998; Goosney et al. 2000; Jenkins et al. 2003). Enterohemorrhagic E. coli (EHEC) causes more serious diarrhea than EPEC, provoking a variety of symptoms that range in severity from acute gastroenteritis to hemorrhagic colitis and in the most severe cases, hemolytic uremic syndrome (HUS) (Goosney et al. 2000), with progression

Editors: Pascale Cossart and Stanley Maloy

Additional Perspectives on Bacterial Pathogenesis available at www.perspectivesinmedicine.org

Copyright (C) 2013 Cold Spring Harbor Laboratory Press; all rights reserved; doi: 10.1101/cshperspect.a009977

Cite this article as Cold Spring Harb Perspect Med 2013;3:a009977 
R.J. Law et al.

to HUS occurring in $15 \%$ of childhood cases (Tarr et al. 2005). The most prevalent EHEC serotype causing outbreaks in North America is $\mathrm{O} 157: \mathrm{H} 7$ with cattle serving as the primary reservoir for this highly infectious organism, thus making EHEC contamination a major issue in food and water safety (Croxen and Finlay 2010). The annual hospitalization rate for laboratory-confirmed EHEC O157 infections is $46.2 \%$ compared with that of non-O157 Shiga toxin-producing $E$. coli infections with a rate of only $12.8 \%$ (Scallan et al. 2011).

EPEC and EHEC belong to a group of extracellular pathogens characterized by their ability to form distinctive pedestal-like structures on the surfaces of intestinal epithelial cells (IEC) (Goosney et al. 2000). This characteristic lesion, known as the attaching and effacing (A/E) lesion, is produced through subversion of hostcell actin dynamics mediated by the bacterial translocated intimin receptor, Tir (Kalman et al. 1999; Gruenheid et al. 2001). EPEC and EHEC are normally noninvasive enteric pathogens, and their intimate attachment to intestinal surfaces is a hallmark of $\mathrm{A} / \mathrm{E}$ pathogen infection requiring the bacterial outer membrane protein, intimin, and the secreted effector, Tir (Kenny et al. 1997). EPEC and EHEC deliver effector proteins into host cells via a type III secretion system (T3SS) encoded on a conserved pathogenicity island known as the locus of enterocyte effacement (LEE) (McDaniel et al. 1995). The LEE is found in all A/E pathogens and is absolutely required for their pathogenesis (Kenny 2002). Encoded within the LEE are regulatory elements, seven secreted effectors and their related chaperones, as well as the T3SS apparatus itself (Frankel et al. 1998b; Deng et al. 2004). In addition to Tir, the T3SS translocates an assortment of effector proteins into host cells, which subvert cellular processes to promote A/E pathogen infection (Kenny 2002; Dean et al. 2005; Wong et al. 2011). To date, several LEE-encoded effectors, as well as a number of non-LEE (Nle)-encoded effectors (Deng et al. 2004), have been identified in the genomes of EPEC and EHEC (Tobe et al. 2006; Coburn et al. 2007; Iguchi et al. 2009).

Effector proteins perform pivotal roles during T3SS-mediated disease by subverting host defenses and cellular trafficking and by manipulating the host cytoskeleton (Fig. 1) (Coburn et al. 2007). The seven LEE-encoded type III secreted (T3S) effectors as well as some of the Nle effectors are well conserved across A/E pathogen species, whereas the number and type of other Nle effectors varies significantly (Dean and Kenny 2009). The prototypic EPEC strain E2348/69 encodes 23 effectors (Iguchi et al. 2009; Deng et al. 2012), whereas certain serotypes of EHEC encode as many as 41 (Tobe et al. 2006; Ogura et al. 2009). Likewise, there is considerable variation in the number of effectors found among A/E animal pathogens such as Citrobacter rodentium (Deng et al. 2010), which colonizes mice (Luperchio and Schauer 2001). The variation in effector repertoire among A/E pathogens likely reflects differences in virulence phenotypes and adaptation to diverse host environments (Tobe et al. 2006; Deng et al. 2010).

EPEC and EHEC are strictly human enteric pathogens, but the availability of surrogate animal models, in addition to the advent of tissue culture, has made it possible to study the complex interactions between these pathogens and their hosts (Vallance et al. 2004). In vitro models such as IEC in tissue culture and in vitro organ culture (IVOC) have been used extensively to define, at the molecular level, T3SS-related proteins necessary for effector secretion and $\mathrm{A} / \mathrm{E}$ lesion formation, as well as effector localization, function, and protein interactions within host cells. Alternatively, in vivo models including nematodes, mice, rabbits, as well as studies in human volunteers, provide essential information with respect to virulence, host immunity and how the inflammatory response contributes to the pathology of A/E pathogen-mediated disease, and the interplay with the microbiota. Current research into the mechanisms of EPEC/EHEC-induced diarrheal disease and the inflammatory response of the host has extended our knowledge of how A/E pathogens infect their hosts and how the immune response they elicit contributes to disease pathogenesis. Further elucidation of the molecular and innate immune mechanisms behind EPEC/EHEC pathogenesis through in vitro and in vivo modeling is crucial to better understand the viru- 


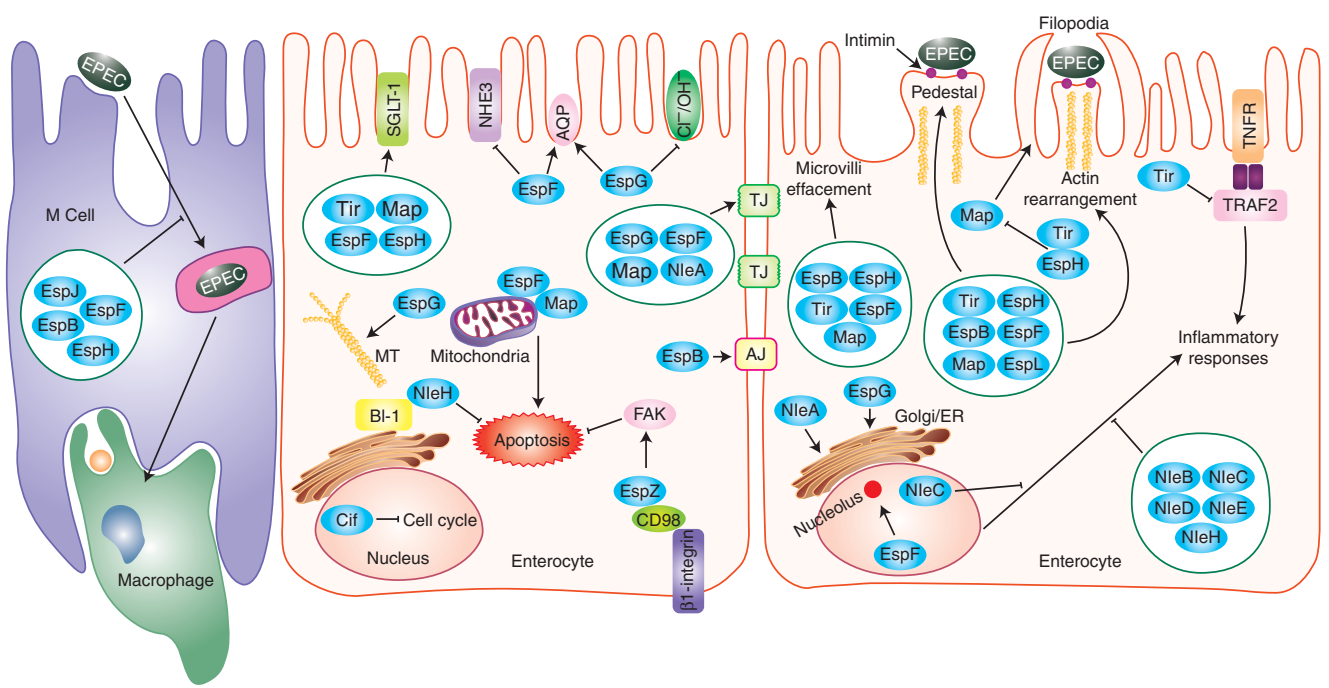

Figure 1. Major T3SS effectors of EPEC/EHEC and their targets within host cells. Adapted and updated with additional information from Dean and Kenny (2009) to show the multifunctional nature of effectors common to EPEC and EHEC and their overlapping functions. TJ, tight junction; AJ, adherens junction; ER, endoplasmic reticulum; MT, microtubules; SGLT-1, sodium glucose cotransporter; NHE3, sodium hydrogen exchanger; AQP, aquaporin; $\mathrm{Cl}^{-} / \mathrm{OH}^{-}, \mathrm{Cl}^{-} / \mathrm{OH}^{-}$transporter; FAK, focal adhesion kinase; BI-1, BAX inhibitor-1; TNFR, tumor necrosis factor receptor; TRAF2, TNF-associated factor 2.

lence strategies used by these organisms in causing disease.

\section{IN VITRO INFECTION MODELS}

Interaction of EPEC with tissue culture cells represents a simple, yet extremely powerful model system for studying A/E pathogens (Fig. 2). EPEC exhibits tight specificity to IEC of the pediatric small intestine during natural infection. Intriguingly, under tissue culture conditions, this selectivity is lost and EPEC interacts with cells originating from a large variety of tissues and species. Although this precludes the use of cell lines to study species specificity and tissue tropism of EPEC, it opens up the opportunity for using specialized cell lines, including those containing specific mutations, to address the role of specific host genes and proteins in a given process. Many features of commonly used cell lines have been characterized, making them an effective tool for studying the role of a given host cell protein in response to bacterial infection.
Although nonpolarized cell lines, such as HeLa cells, are very different from polarized cells of the intestinal epithelium, they have been used extensively to study basic aspects of the EPEChost interaction. The best evidence in support of adopting such cell lines as model systems to study EPEC is the dissection of actin pedestal biogenesis, including the elucidation of the involved bacterial and host proteins. Early studies showed the process of actin pedestal formation during infection of tissue culture cells (Knutton et al. 1989; Rosenshine et al. 1996), which provided a solid foundation for several seminal discoveries based on the molecular mechanisms of pedestal formation during infection with $\mathrm{A} / \mathrm{E}$ pathogens (reviewed in Frankel and Phillips 2008 and Campellone 2010). Additional examples of the usefulness of nonpolarized cells as models for studying A/E pathogen infection are their use in studies aimed at elucidating the process of T3SS-dependent protein translocation into host cells as well as functional analyses of the injected effectors. These include genetic analysis defining components that are required 
R.J. Law et al.

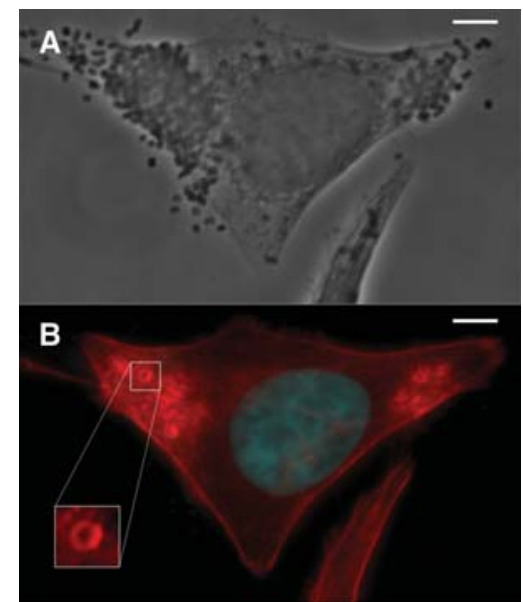

Figure 2. The use of cell culture models to study EPEC pathogenicity. HeLa cells were infected for $3 \mathrm{~h}$ with EPEC and visualized using phase contrast $(A)$, or phalloidin rhodamine (red) and DAPI (cyan) staining $(B)$. The dense F-actin staining (red) is representative of actin pedestals formed beneath the infecting bacteria. Magnification, $100 \times$; scale bar, $5 \mu \mathrm{m}$.

for T3SS assembly and/or activity (reviewed in Cornelis 2006), and analysis of the injection process (Mills et al. 2008). Studies of the biochemical activity of injected effectors also benefit from using tissue culture cells as they are easy to grow and manipulate. This is nicely exemplified by analysis of the function of Tir, as well as most other studied effectors (Nieto-Pelegrin and Martinez-Quiles 2009; Nadler et al. 2010; Baruch et al. 2011). Indeed, simple nonpolarized cell lines provide an effective model system to study basic aspects of T3SS function and the immediate interface between bacterial and host proteins.

Nonpolarized cell lines are not as effective for studying the influence of EPEC/EHEC on the physiological properties of IEC, such as barrier function or maintenance of the brush border. This is particularly true in cases in which the effect on barrier function is secondary. For instance, the effector Map appears to function as a guanine nucleotide exchange factor of Cdc42 GTPase, an activity that results in barrier function disruption (Dean and Kenny 2004). Cell lines that mimic polarization by formation of tight junctions and brush border, including
MDCK, Caco-2, T84, and HT29, provide instrumental models for describing how EPEC disrupts epithelial barrier function during infection and for identifying effectors that are specifically involved in this process (McNamara et al. 2001, and reviewed in Sears 2000). These cell lines offer the advantages of convenience, rapid growth, uniformity, and availability of genetic tools such as antibodies and genetically manipulated cell lines.

In addition to interactions with enterocytes, EPEC also interacts with phagocytic M cells and dendritic cells that extend protrusions into the gut lumen where EPEC may encounter infiltrating innate immune cells (Inman and Cantey 1983; Martinez-Argudo et al. 2007; Vossenkämper et al. 2010). These particular immune cell types are modeled by macrophage-like cell lines such as J774 and U937, and using these models, it was found that EPEC resists uptake by professional phagocytes (Goosney et al. 1999). Macrophage-like cell lines also enabled the identification of EspF, EspJ, and EspH effector functions, in targeting independent aspects of the phagocytic function of mammalian macrophages (Quitard et al. 2006; Marchès et al. 2008; Dong et al. 2010). Macrophage-like cells were also used to show that EspT plays a role in triggering the production of central immune mediators (Raymond et al. 2011).

The physiological relevance of the findings discovered in cultured cell lines needs confirmation in more biologically relevant models. For instance, the use of IVOC has shown that pathways of A/E lesion formation based on cultured cell lines do not necessarily apply in organ culture (Schüller et al. 2007; Bai et al. 2008). The IVOC system is the most complex in vitro model to study EPEC infection (Knutton et al. 1987). This model includes infection of freshly obtained human intestinal biopsies kept in tissue culture media under high oxygen pressure to delay ischemia and cell death. The advantage of IVOC is that the infected tissue is as close as one can get in vitro to native live tissue. In a recent study, an improved polarized version of this model was presented in which the apical surface of the tissue biopsy was affixed to an acrylic glass disk to seal the mucosal side of the 
sample and decrease bacterial leakage to the basolateral surface (Schüller et al. 2009). Thus, the polarized IVOC model allows specific apical EPEC infection that better mimics the in vivo situation. Like other in vitro systems, experimentation time is limited to several hours until the tissue dies and, compared with other in vitro models, the use of IVOC for experimental infection is technically challenging and requires coordination with a clinic to obtain fresh tissue. In addition, the variability in sample properties between donors and results is far greater than in cell line models. The IVOC system has been used to study EPEC-host specificity and tissue tropism (Girard et al. 2005; Mundy et al. 2007), Tir-intimin-dependent colonization and A/E lesion formation (Frankel et al. 1998a; Schüller et al. 2007; Frankel and Phillips 2008). The polarized IVOC method has shown that apical EPEC infection of duodenal mucosa results in a flagellin-dependent increase in IL-8 levels (Schüller et al. 2009).

The use of cell lines for pathogenic E. coli research is very common and extensive. Cell lines simplify very complex in vivo processes, and their use may significantly shorten the duration of research compared with in vivo models. EPEC is a human-specific pathogen and the use of human cell lines enables the study of direct interactions between the bacterium and its natural host cells, making IEC lines an excellent tool to study A/E pathogen-host-cell dynamics. Yet, one must consider that the biological relevance of results obtained via the use of cultured cell lines requires further validation in a relevant in vivo model. In vitro systems lack additional host cell types, immune interactions, natural microflora, and the specific physiological conditions that influence host-microbe interactions in the small intestine.

\section{IN VIVO INFECTION MODELS}

Given the narrow host range of human EPEC, studies exploring the role of genes involved in A/E pathogen virulence and lesion formation have been limited by a lack of in vivo models reflecting the natural disease process in humans. The primary site of infection by EPEC and
EHEC are epithelial cells of the small intestine and colon, respectively. Although much information has been gathered through in vitro analyses with respect to localization and function of T3S effector proteins, in vivo systems are the only way of assessing A/E pathogen virulence within the context of the complete intestinal environment. A/E bacteria are able to infect diverse animal species (Wales et al. 2005) from the invertebrate Caenorhabditis elegans to mice, rabbits, pigs, and cattle. As such, the diversity of available animal models has provided the research community with a wealth of potential hosts with which to simulate the various aspects of human infection.

C. elegans is a small free-living nematode that has traditionally been used for the study of development, neurobiology, and aging (Brenner 1974; Larsen et al. 1995), but has garnered interest as a model to study microbial virulence strategies and conserved mechanisms of innate immunity (Kurz and Ewbank 2000; Schulenburg et al. 2004; Hilbi et al. 2007). The simplicity of the nematode provides an inexpensive and uncomplicated model in which to follow the infection process. In 1999, Tan et al. first reported the utility of $C$. elegans as a model for feeding-based pathogenicity studies using the opportunistic pathogen Pseudomonas aeruginosa (Tan et al. 1999). Like P. aeruginosa, EPEC has been shown to both infect and kill C. elegans via a "slow killing" mechanism resulting from bacterial accumulation in the nematode intestine, as well as to form microcolonies similar to those formed during EPEC infection of cultured epithelial cells (Mellies et al. 2006). On the other hand, EPEC has also been reported to cause paralysis and death of C. elegans via a "fast killing" mechanism involving secretion of diffusible exotoxins (Anyanful et al. 2005; Bhatt et al. 2011). The usefulness of the nematode as a simple animal model for the study of EPEC pathogenesis is validated by the fact that mutation-based analysis of specific genes required for full virulence of EPEC in mammalian systems are similarly required for maximum pathogenicity in the nematode. For example, the global virulence regulator Ler is essential for virulence of rabbit enteropathogenic E. coli (REPEC) and 
R.J. Law et al.

C. rodentium in the weaned rabbit and mouse models of infection, respectively (Deng et al. 2004; Zhu et al. 2006), and is similarly required for colonization of $C$. elegans by EPEC (Mellies et al. 2006). In addition, EPEC is shown to elicit a protective response in $C$. elegans through induction of genes regulating nematode innate immunity in response to pathogen exposure (Anyanful et al. 2009). C. elegans provides a straightforward in vivo system in which to study EPEC attachment and colonization factors (Mellies et al. 2006), however, practical limitations to this model do exist as C. elegans cannot survive at the optimal temperature required for expression of the virulence machinery of $\mathrm{A} / \mathrm{E}$ pathogens (Umanski et al. 2002). Furthermore, administration of precise bacterial inocula can be technically difficult (Mylonakis and Aballay 2005). Additionally, although some degree of conservation exists between innate immunity pathways of the nematode and those of higher organisms (2003), and nonmammalian vertebrate models like the zebrafish have been used to study neutrophil modulation during EHEC infection (Szabady et al. 2009), mammalian models such as mice and rabbits are more representative of the inflammatory response seen during human EPEC/EHEC infection.

Although EPEC and EHEC display narrow host specificity and are primarily human pathogens (Goosney et al. 2000), mouse models of infection have also been reported. Savkovic et al. found that infection of $\mathrm{C} 57 \mathrm{BL} / 6$ mice with EPEC resulted in colonization and adherence to the intestinal epithelium as well as distortion and loss of intestinal microvilli concomitant with actin accumulation at the site of EPEC infection (Savkovic et al. 2005), all of which is consistent with A/E lesion formation. Recent studies using this model to investigate changes in tight junction morphology and epithelial barrier function in mice as a result of EPEC infection found that infections were accompanied by an inflammatory response in the intestines of infected mice (Zhang et al. 2010a,b). In both cases, wild-type EPEC induced inflammatory cell infiltration and tissue damage similar to what has been previously reported (Savkovic et al. 2005). Conversely, several EPEC deriva- tives were unable to colonize Swiss NIH mice (Frankel et al. 1996) and Klapproth et al. found that EPEC was rapidly cleared from the intestines of infected C57BL/6 mice with no evidence of $\mathrm{A} / \mathrm{E}$ lesion formation (Klapproth et al. 2005). Similarly, a study comparing the colonization dynamics of $\mathrm{C} 3 \mathrm{H} / \mathrm{HeJ}$ and $\mathrm{C} 57 \mathrm{BL} / 6$ mice infected with EPEC, EHEC, or C. rodentium found very low levels of EPEC/EHEC colonization with no apparent signs of pathology (Mundy et al. 2006). This was in contrast to mice infected with $C$. rodentium that showed high levels of colonization accompanied by increased intestinal weights and visible thickening of the colon (Mundy et al. 2006). These data suggest a limited application for the model due to the inconsistency in EPEC colonization levels and manifestation of A/E pathogen-associated hallmarks of disease among several laboratory mouse strains.

Streptomycin-treated mouse models have also been used to study the colonization dynamics of EPEC and EHEC by eliminating or reducing normal gut microbial communities to avoid competitive exclusion and facilitate colonization (Royan et al. 2010; Mohawk and O'Brien 2011). Bioluminescent strains of EPEC and EHEC show tight association of the bacteria with cecal and colonic tissues of streptomycintreated mice accompanied by mild inflammation (Roxas et al. 2010; Rhee et al. 2011) and, in the case of EHEC, microvilli effacement (Roxas et al. 2010). Germ-free mice have been used to study toxin suppression and production of other virulence factors by EHEC as well as the use of probiotics for protection against colonization and EHEC-mediated disease (Takahashi et al. 2004; Eaton et al. 2008, 2011). Alternatively, human xenografts of the small and large intestine in severe combined immunodeficiency mice have recently been proposed as a model to evaluate T3S effector function in native tissue and to investigate tissue tropism (Golan et al. 2011). EHEC is able to specifically interact with human colonic xenografts, inducing A/E lesions and tissue damage dependent on a functional T3SS (Golan et al. 2011). This type of model has also been used to show that $\mathrm{H} 7 \mathrm{fla}-$ gellin is a major factor involved in increases of 
proinflammatory chemokines in response to EHEC infection (Miyamoto et al. 2006). An advantage of this model is the ability to study the immunogenic reaction of $\mathrm{A} / \mathrm{E}$ pathogens in the absence of other microbial products. However, both the xenograft and streptomycin pretreatment models are limited in their capacity to assess A/E pathogen infection under physiologically relevant conditions that take into account the complete intestinal mucosa and interactions with the resident microflora.

A great deal of in vivo research on A/E pathogens has been performed using natural animal pathogens related to EPEC and EHEC. Infection of rabbits and mice with REPEC and $C$. rodentium, respectively, has been used to study the contributions of many translocated effectors and T3SS-related genes to EPEC virulence and disease. REPEC encompasses a number of serotypes of A/E lesion-forming, diarrheagenic E. coli that share many virulence characteristics with human EPEC and are capable of causing diarrheal disease in weaned rabbits (Goosney et al. 2000). Similar to human-specific EPEC strains, REPEC induces A/E lesions and intestinal pathology without invasion of the epithelia or production of enterotoxins (RobinsBrowne et al. 1994b). The REPEC LEE has been characterized and shares a high degree of homology with the LEE region of EPEC (Tauschek et al. 2002), thereby facilitating the discovery of LEE genes required for A/E lesion formation and disease (Abe et al. 1998; Marchès et al. 2000).

The LEE of $C$. rodentium is also similar to those of EPEC and EHEC (Deng et al. 2001) and is required to produce $\mathrm{A} / \mathrm{E}$ lesions in mouse intestinal cells (Schauer and Falkow 1993). Functional conservation of Tir and intimin from EPEC and C. rodentium has been shown and confirms the usefulness of the C. rodentium-mouse model to study human infections with EPEC and EHEC (Fig. 3) (Frankel et al. 1996; Deng et al. 2003). However, instead of causing obvious diarrhea as seen with EPEC, EHEC, and REPEC, C. rodentium infection results in colonic inflammation and hyperplasia (Barthold et al. 1978). Despite this difference, mouse infections with $C$. rodentium have con-

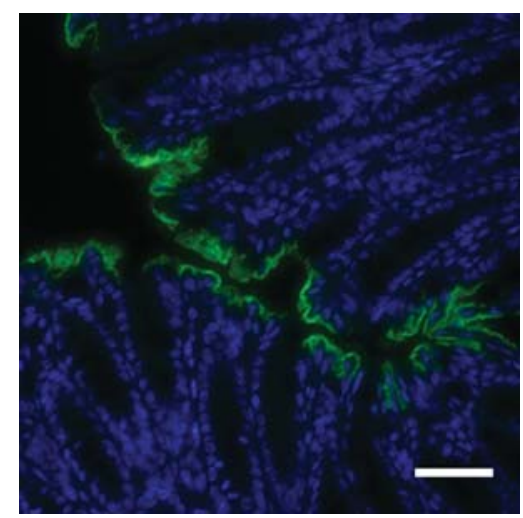

Figure 3. C. rodentium colonizes the apical surfaces of mouse intestinal epithelial cells (IEC) in vivo. Mice were orally infected with $C$. rodentium and colonic tissues were harvested and subjected to immunofluorescent staining at 6 days postinfection. Immunostaining was performed using a $C$. rodentium-specific anti-Tir antibody (green) with DAPI (blue) as a counterstain for host-cell nuclei. Magnification, $40 \times$; scale bar, $50 \mu \mathrm{m}$. For further details, see Wlodarska et al. (2011).

tributed significantly to our understanding of A/E pathogen virulence and mechanisms of disease in vivo. Using the mouse model 33 virulence factors were identified during a screen of all 41 genes in the $C$. rodentium LEE (Deng et al. 2004). A comprehensive analysis of the C. rodentium secretome has since been performed, effectively confirming secretion of many previously identified effectors while expanding the known repertoire of T3S proteins among A/E pathogens (Deng et al. 2010). Although much of the in vivo work on $\mathrm{A} / \mathrm{E}$ pathogens has focused on the virulence roles of secreted proteins, others have attempted to determine tissue localization of effectors such as Tir (Deng et al. 2003), in an effort to uncover function. Infection of mice with $C$. rodentium mutants confirms a critical role in colonization and virulence of the LEE-encoded effectors Tir, EspB, and EspZ, as well as the non-LEE-encoded effectors NleA and NleB (Newman et al. 1999; Deng et al. 2003, 2004; Gruenheid et al. 2004; Mundy et al. 2004; Kelly et al. 2006), whereas others are thought to contribute collectively (Dean and Kenny 2009). 
R.J. Law et al.

A/E pathogens encode a series of secreted proteins believed to interfere with various host inflammatory signaling pathways (Dean and Kenny 2009; Wong et al. 2011). Thus, another significant advantage to the use of in vivo models is the ability to assess host-generated immune responses to bacterial infections. The $C$. rodentium mouse model has been widely used to explore the host immune response to pathogenic E. coli infections (Luperchio and Schauer 2001; Borenshtein et al. 2008; Kum et al. 2010). In susceptible mice, $C$. rodentium induces colonic hyperplasia and intestinal inflammation and mice often die as a result of infection, whereas less susceptible mouse strains are generally able to clear these infections (Luperchio and Schauer 2001) and develop a protective response against subsequent infection (GhaemMaghami et al. 2001). The role of IL-22 in regulating early control of host defense in response to $C$. rodentium infection has been shown (Zheng et al. 2008; Ota et al. 2011). Direct induction of Reg antimicrobial proteins requires IL-22 in the colonic epithelium, and survival of IL-22 knockout mice infected with $C$. rodentium is greatly improved in the presence of exogenous mouse or human RegIII $\gamma$ (Zheng et al. 2008). Mice that lack adaptive immunity of $B$ and $\mathrm{T}$ lymphocytes are unable to efficiently clear C. rodentium infection (Vallance et al. 2002; MacDonald et al. 2003), as are mice lacking the p50 subunit of nuclear factor $\kappa \mathrm{B}$ (NF$\kappa \mathrm{B})$ (Dennis et al. 2008) and the Toll-like receptor adapter protein MyD88 (Lebeis et al. 2007; Gibson et al. 2008). Furthermore, sensitivity to C. rodentium is strongly influenced by the presence of segmented filamentous bacteria of the intestinal microbiota (Ivanov et al. 2009). Taken together, these studies provide clear evidence that both innate and adaptive immune pathways, as well as components of the microbiota, have a protective role against $\mathrm{A} / \mathrm{E}$ pathogen infection and future in vivo work should help to shed more light on how different branches of the immune system respond to these infections.

Recent progress in the identification of T3SS structural proteins and secreted effectors has advanced our knowledge of $\mathrm{A} / \mathrm{E}$ pathogenesis substantially at the molecular level, but the rel- evance of these proteins in EPEC and EHEC and their functions during human infection can only be validated through the use of human volunteers. Adult volunteers have been used to verify the roles of intimin, EspB, and bundle-forming pili (BFP) in EPEC pathogenesis (Donnenberg et al. 1993; Bieber et al. 1998; Tacket et al. 2000). BFP is an EPEC-specific virulence factor but intimin and $\mathrm{EspB}$ are found in the genomes of diverse A/E pathogen species (Tauschek et al. 2002; Iguchi et al. 2009; Ogura et al. 2009; Petty et al. 2010). Intimin and EspB are essential for A/E lesion formation in tissue culture (Foubister et al. 1994; Abe et al. 1997) and intestinal damage in rabbits and mice infected with REPEC (Abe et al. 1998; Marchès et al. 2000) or C. rodentium, respectively (Schauer and Falkow 1993; Newman et al. 1999; Deng et al. 2004). Intestinal biopsies taken from human volunteers infected with wild-type EPEC show destruction of the epithelial brush border (Tacket et al. 2000), a phenotype that is reproducible in tissue culture (Knutton et al. 1987). All but one individual developed diarrhea after consumption of the wild-type strain (Tacket et al. 2000), whereas only one instance of diarrhea occurred in 10 individuals who consumed the $\operatorname{esp} B$ mutant (Tacket et al. 2000) and four out of 11 who consumed the intimin mutant (Donnenberg et al. 1993). Due to the relative inability of most EPEC strains to colonize nonhuman hosts and cause diarrhea, clinical trials using adult volunteers are important to further our knowledge of EPEC pathogenesis in humans and to determine the role of specific virulence factors in EPEC-mediated disease (Tacket et al. 2000). However, the use of human volunteer studies is not without its drawbacks as the diarrhea that develops is often not reproducible (Donnenberg et al. 1993) and susceptibility among individual hosts is likely to vary based on differences in immune response and prior exposure to the pathogen. Additionally, the tendency for EPEC and EHEC to infect and cause disease in young children (Kaper et al. 2004) and the varying degree of disease severity associated with EHEC infections (Nataro and Kaper 1998) precludes the use of appropriate volunteer populations, thus making the 
EPEC Infection Models

identification of host resistance genes difficult. As a result, surrogate models using related $\mathrm{A} / \mathrm{E}$ pathogens and their natural animal hosts have given way to important advances in the pathogenesis of EPEC and EHEC (Vallance et al. 2004).

\section{COMPARISON OF MODELS}

No model system currently in use for the study of EPEC/EHEC pathogenesis is able to completely replicate the natural infection process in humans. However, each model does have its particular advantages and it is the combination of all these models that has advanced our knowledge on $\mathrm{A} / \mathrm{E}$ pathogens tremendously over the last 20 years (Fig. 4). An area of increasing interest in $\mathrm{A} / \mathrm{E}$ pathogen research involves identifying cellular receptors for T3S effectors once inside host cells. Tissue culture methods have been used successfully to identify a few host targets and functions for a number of secreted effectors. Infection of immortalized epithelial cells provides a simple and convenient means to assess the direct relationship between the infecting organism and the intestinal epithelia in the absence of additional host and mi- crobial factors that would normally be present within the lumen. In comparison to nonpolarized epithelial cells, Caco-2 and T84 cells are capable of mimicking polarized enterocytes of the small and large intestine, respectively, and have additionally been used to study the effects of EPEC infection on tight junction integrity and overall intestinal barrier function (McNamara et al. 2001; Dean and Kenny 2004; Thanabalasuriar et al. 2010). Alternatively, polarized intestinal IVOC systems also provide an excellent in vitro model for studying EPEC infection of the intestinal mucosa because $\mathrm{A} / \mathrm{E}$ pathogen exposure can be restricted to mucosal tissue surfaces, thereby simulating natural infection (Schüller et al. 2009). Because polarized IVOC maintains tissue structure and membrane integrity similar to in vivo systems, this method is far more conducive to determining the significance of effector protein distribution during infection and modeling in vivo colonization dynamics than infection of cell lines. However, human intestinal specimens are not as readily available to most laboratories as standard tissue culture cell lines (Vallance et al. 2004). Additionally, the short life span of cultured organ sections and the inability of in vitro systems to metabolize

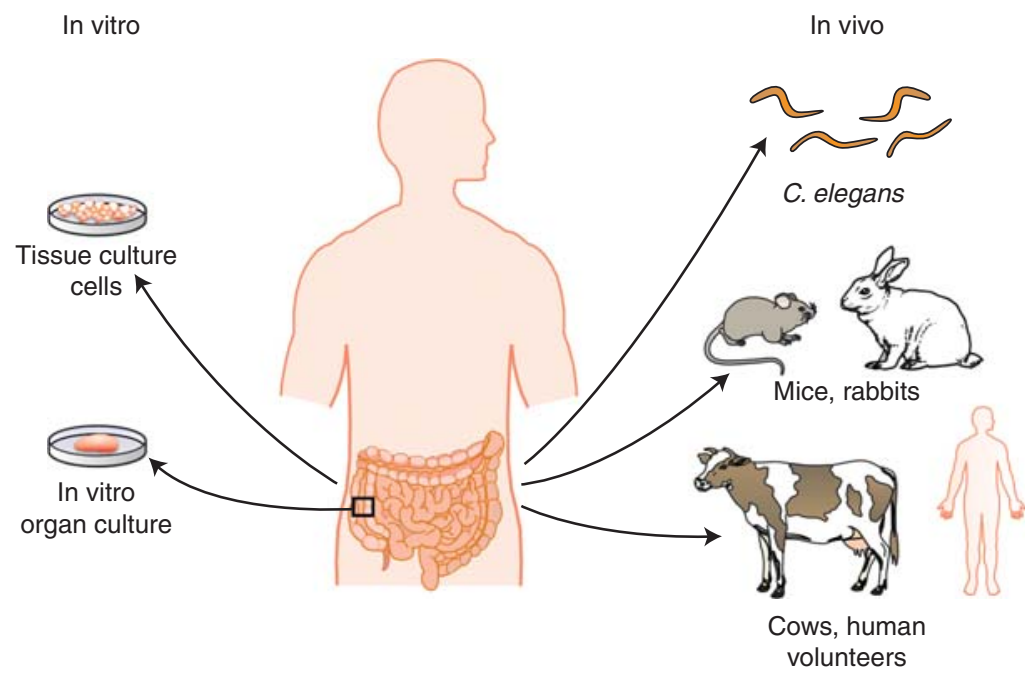

Figure 4. The various model systems currently available to study EPEC/EHEC infection biology. In vitro models such as tissue culture cells and in vitro organ culture (IVOC) are best suited to assess bacteria-host-cell interactions such as pedestal formation, signal transduction, effector translocation, and effector function. Alternatively, in vivo models are more appropriate for studies on bacterial virulence and host immune response. 
R.J. Law et al.

drug candidates render these models ineffective for drug action studies in comparison to whole animal models.

Cell culture methods provide important information with respect to the cellular biology of T3S effector function, but are of limited use in studying the interaction of $\mathrm{A} / \mathrm{E}$ pathogens with the host immune system and microbiota. Related $\mathrm{A} / \mathrm{E}$ animal pathogens, infecting their natural hosts, have come to serve as effective models for EPEC/EHEC pathogenesis although not all are capable of causing equivalent intestinal disease in their animal hosts. For example, mice infected with $C$. rodentium tend to develop colonic hyperplasia accompanied by soft stool and rectal prolapse (Luperchio and Schauer 2001), whereas infection of children by EPEC can result in copious and often fatal watery diarrhea (Nataro and Kaper 1998). As natural pathogens of rabbits and mice, REPEC and C. rodentium provide highly relevant surrogate models to study EPEC infection in humans. Rabbits naturally develop severe and often lethal diarrhea in response to REPEC infection (RobinsBrowne et al. 1994a) and with the exception of initial host-cell attachment, REPEC displays the same pathological characteristics, host age, and tissue specificity as human EPEC (RobinsBrowne et al. 1994b), making this one of the most applicable models for studying EPEC infection. Limitations to this model do exist, however, in that few genetic tools are available to evaluate the host response to REPEC infection, and due to the significant mortality resulting from this infection, modest differences in virulence are difficult to detect (Vallance et al. 2004). C. rodentium, on the other hand, naturally infects mice of all ages and offers the convenience of several genetic and immunological tools to study infection and host response, including a variety of genetically manipulated mouse strains (Vallance et al. 2004). In addition, increasing interest on the essential role of the intestinal microbiota in maintaining overall gut homeostasis as well as protection against enteric pathogens offers another level of complexity to A/E pathogen infection that can only be assessed in vivo. Disruption or elimination of normal gut microbial communities could lead to altered epithelial cell responses and host susceptibility to infection (Sekirov and Finlay 2009; Wlodarska et al. 2011). Thus, a more detailed understanding of the mechanisms behind the host-pathogen-microbiota interaction should lead to an improved therapeutic approach in managing $\mathrm{A} / \mathrm{E}$ pathogen infection. Animal models provide a convenient means to study A/E pathogens, yet the symptoms and severity of diarrheal disease can vary significantly between animal hosts. Although the clinical outcome of EPEC or EHEC infection in humans differs from that of $C$. rodentium in mice, this model remains the best for studies on host immune response to $\mathrm{A} / \mathrm{E}$ pathogen infection. However, heavier costs associated with housing and handling of animals, as well as increased complexity of the gastrointestinal environment in comparison to in vitro infection models, are major limitations of in vivo systems (Table 1).

Currently, there is no vaccine available to humans to prevent infection by EPEC or EHEC, and the use of antibiotics for treatment of EHEC infections is controversial as certain antibiotics may exacerbate disease symptoms (Panos et al. 2006), as well as induce Shiga toxin production. Numerous EHEC outbreaks have been traced back to ingestion of contaminated beef and vegetable products (Nataro and Kaper 1998; Berger et al. 2010). Although a major environmental reservoir for EPEC has not yet been determined, it is generally accepted that transmission to humans occurs through contaminated food and water sources (Nataro and Kaper 1998). As a result, reducing carriage and transmission of EHEC in cattle as well as bacterial attachment to and colonization of produce are important areas of $\mathrm{A} / \mathrm{E}$ pathogen research. A logical approach to preventing infections in humans has therefore been to immunize cattle to reduce colonization and fecal shedding to the environment. In vivo models such as mice, pigs, and cattle have all been used to study essential virulence factors conserved between EPEC and EHEC as potential vaccine candidates (DeanNystrom et al. 2002; Potter et al. 2004; McNeilly et al. 2010; Misyurina et al. 2010; Mohawk and O'Brien 2011). Thus, the EPEC/EHEC T3SS 
EPEC Infection Models

Table 1. Summary of in vitro and in vivo infection models

\begin{tabular}{|c|c|c|c|}
\hline & Advantages & Disadvantages & Applications \\
\hline \multicolumn{4}{|c|}{ In vitro models } \\
\hline Cell lines & $\begin{array}{l}\text { Simplicity, uniformity, rapid } \\
\text { growth, availability of } \\
\text { human cells, and knockout } \\
\text { cell lines }\end{array}$ & $\begin{array}{l}\text { Infection times limited by bacterial } \\
\text { overgrowth, limited ability to } \\
\text { assess host response, do not } \\
\text { necessarily represent physiology } \\
\text { in vivo }\end{array}$ & $\begin{array}{l}\text { Effector function and } \\
\text { translocation, pedestal } \\
\text { formation, bacteria- } \\
\text { host-cell interactions }\end{array}$ \\
\hline IVOC & $\begin{array}{l}\text { Enables research in human } \\
\text { tissues, maintains tissue } \\
\text { structure/membrane } \\
\text { integrity, similar to in vivo } \\
\text { system }\end{array}$ & $\begin{array}{l}\text { Low availability of human tissue } \\
\text { biopsies, short life span of tissue } \\
\text { limits experimentation, } \\
\text { variation between samples }\end{array}$ & $\begin{array}{l}\text { Host specificity, tissue } \\
\text { tropism, colonization } \\
\text { dynamics }\end{array}$ \\
\hline \multicolumn{4}{|c|}{ In vivo models } \\
\hline Invertebrate & $\begin{array}{l}\text { Simple, inexpensive, rapid } \\
\text { generation time, availability } \\
\text { of knockout mutants }\end{array}$ & $\begin{array}{l}\text { Cannot survive at mammalian } \\
\text { body temperature, no adaptive } \\
\text { immune system, difficult to } \\
\text { deliver precise inocula }\end{array}$ & $\begin{array}{l}\text { Colonization and } \\
\text { attachment factors, } \\
\text { microbial virulence }\end{array}$ \\
\hline Mammalian & $\begin{array}{l}\text { Availability of knockout mice, } \\
\text { can assess innate and } \\
\text { adaptive immune responses, } \\
\text { can assess pathogen } \\
\text { virulence }\end{array}$ & $\begin{array}{l}\text { Increased cost and complexity, } \\
\text { subject variability, no model } \\
\text { replicates all aspects of human } \\
\text { infection }\end{array}$ & $\begin{array}{l}\text { Microbial virulence, host } \\
\text { immune response, } \\
\text { effects of host } \\
\text { microbiota, vaccine trials }\end{array}$ \\
\hline
\end{tabular}

See text for references. IVOC, in vitro organ culture.

and secreted proteins offer attractive targets for development of novel vaccines and therapeutics whose effectiveness can only be evaluated through in vivo experimentation.

\section{CONCLUDING REMARKS}

Diarrheagenic E. coli present a significant risk to human health worldwide, and due to the severity of symptoms associated with infections caused by EPEC and EHEC, few opportunities have presented themselves to study host susceptibility to these microbes and disease pathogenesis in the human host. For this reason, a variety of infection models have been developed to provide insight into our current understanding of the virulence mechanisms employed by A/E bacterial pathogens and to explore the molecular mechanisms that contribute to virulence of pathogenic E. coli. In vitro systems are ideal for assessing the cellular biology of T3S effector function and the bacterial-host-cell interactions that contribute to initial attachment and colonization. In contrast, in vivo infection models are crucial to identify and differentiate between virulence factors that may be common to all $\mathrm{A} / \mathrm{E}$ pathogens and those that are specific to EPEC and EHEC, as well as to determine the basis for host resistance or susceptibility to these pathogens to properly control the public health burdens that they impose (Vallance et al. 2004).

New and rapidly evolving genomic tools are emerging, allowing for novel revelations of how differences in gut microbial composition and variability of the human metagenome among individuals correlate with human health and disease states (Arumugam et al. 2011; Pflughoeft and Versalovic 2011). In the future, global surveys of the human metagenome should address how the composition of the microflora and the genome of the individual contribute to host susceptibility to A/E pathogens, whether in a carrier state or during acute infection. Studies of this nature should provide information that will lead to a better understanding of the infection process as it relates to host- 
R.J. Law et al.

pathogen-microbiota interplay. Currently, no in silico models exist to directly simulate EPEC or EHEC infection (Vallance et al. 2004), however, publication of the EPEC E2348/69 (Iguchi et al. 2009), EHEC O157:H7 (Hayashi et al. 2001; Perna et al. 2001), and C. rodentium (Petty et al. 2010) genome sequences has facilitated identification of conserved and unique T3SSrelated proteins and effectors and should contribute to the development of microarray databases and other computer-based technologies to identify and study $\mathrm{A} / \mathrm{E}$ bacterial pathogens.

Major advances in A/E pathogen research have been made over the years through the use of different EPEC/EHEC infection models. Novel adherence factors and secreted effectors have been identified and for many of these proteins, their mechanism of action and host receptors have been determined. However, to fully understand how these molecular interactions contribute to disease, in vivo studies are required to show a direct impact by A/E pathogen virulence. A more detailed understanding of how EPEC and EHEC exploit cellular functions as part of the disease process could ultimately lead to potential targets for new therapeutics to help control these significant enteric pathogens.

\section{ACKNOWLEDGMENTS}

We thank Y. Litvak from the Hebrew University of Jerusalem and M. Wlodarska from the University of British Columbia for providing fluorescent images. We also thank members of the Finlay and Rosenshine laboratories for constructive comments and critical reading of the manuscript. Work in B.B.F.'s laboratory is supported by an operating grant from the Canadian Institute of Health Research (CIHR). Work in I.R.'s laboratory is supported by grants from the Israel Science Academy of Science and Humanities, the Israeli Ministry of Health, and the German Israeli Science Foundation (GIF). R.J.L. is supported by a Natural Sciences and Engineering Research Council of Canada (NSERC) Postgraduate scholarship. I.R. is an Etta Rosensohn Professor of Bacteriology. B.B.F. is the UBC Peter Wall Distinguished Professor.

\section{REFERENCES}

Abe A, Kenny B, Stein M, Finlay BB. 1997. Characterization of two virulence proteins secreted by rabbit enteropathogenic Escherichia coli, EspA and EspB, whose maximal expression is sensitive to host body temperature. Infect Immun 65: 3547-3555.

Abe A, Heczko U, Hegele RG, Finlay BB. 1998. Two enteropathogenic Escherichia coli type III secreted proteins, EspA and EspB, are virulence factors. J Exp Med 188: 1907-1916.

Anyanful A, Dolan-Livengood JM, Lewis T, Sheth S, Dezalia MN, Sherman MA, Kalman LV, Benian GM, Kalman D. 2005. Paralysis and killing of Caenorhabditis elegans by enteropathogenic Escherichia coli requires the bacterial tryptophanase gene. Mol Microbiol 57: $988-$ 1007.

Anyanful A, Easley KA, Benian GM, Kalman D. 2009. Conditioning protects $C$. elegans from lethal effects of enteropathogenic E. coli by activating genes that regulate lifespan and innate immunity. Cell Host Microbe 5: 450-462.

Arumugam M, Raes J, Pelletier E, Le Paslier D, Yamada T, Mende DR, Fernandes GR, Tap J, Bruls T, Batto JM, et al. 2011. Enterotypes of the human gut microbiome. Nature 473: $174-180$.

Bai L, Schüller S, Whale A, Mousnier A, Marches O, Wang L, Ooka T, Heuschkel R, Torrente F, Kaper JB, et al. 2008. Enteropathogenic Escherichia coli O125:H6 triggers attaching and effacing lesions on human intestinal biopsy specimens independently of $\mathrm{Nck}$ and $\mathrm{TccP} / \mathrm{TccP} 2$. Infect Immun 76: 361-368.

Barthold SW, Coleman GL, Jacoby RO, Livestone EM, Jonas AM. 1978. Transmissible murine colonic hyperplasia. Vet Pathol 15: 223-236.

Baruch K, Gur-Arie L, Nadler C, Koby S, Yerushalmi G, BenNeriah Y, Yogev O, Shaulian E, Guttman C, Zarivach R, et al. 2011. Metalloprotease type III effectors that specifically cleave JNK and NF-кB. EMBO J 30: 221-231.

Berger CN, Sodha SV, Shaw RK, Griffin PM, Pink D, Hand P, Frankel G. 2010. Fresh fruit and vegetables as vehicles for the transmission of human pathogens. Environ Microbiol 12: 2385-2397.

Bhatt S, Anyanful A, Kalman D. 2011. CsrA and TnaB coregulate tryptophanase activity to promote exotoxininduced killing of Caenorhabditis elegans by enteropathogenic Escherichia coli. J Bacteriol 193: 4516-4522.

Bieber D, Ramer SW, Wu CY, Murray WJ, Tobe T, Fernandez R, Schoolnik GK. 1998. Type IV pili, transient bacterial aggregates, and virulence of enteropathogenic Escherichia coli. Science (New York, NY) 280: 2114-2118.

Borenshtein D, McBee ME, Schauer DB. 2008. Utility of the Citrobacter rodentium infection model in laboratory mice. Curr Opin Gastroenterol 24: 32-37.

Brenner S. 1974. The genetics of Caenorhabditis elegans. Genetics 77: 71-94.

Campellone KG. 2010. Cytoskeleton-modulating effectors of enteropathogenic and enterohaemorrhagic Escherichia coli: Tir, EspFU and actin pedestal assembly. FEBS J 277: 2390-2402.

Coburn B, Sekirov I, Finlay BB. 2007. Type III secretion systems and disease. Clin Microbiol Rev 20: 535-549. 
Cornelis GR. 2006. The type III secretion injectisome. Nat Rev Microbiol 4: 811-825.

Croxen MA, Finlay BB. 2010. Molecular mechanisms of Escherichia coli pathogenicity. Nat Rev Microbiol 8: 2638

Dean P, Kenny B. 2004. Intestinal barrier dysfunction by enteropathogenic Escherichia coli is mediated by two effector molecules and a bacterial surface protein. $\mathrm{Mol} \mathrm{Mi-}$ crobiol 54: 665-675.

Dean P, Kenny B. 2009. The effector repertoire of enteropathogenic E. coli: Ganging up on the host cell. Curr Opin Microbiol 12: 101-109.

Dean P, Maresca M, Kenny B. 2005. EPEC's weapons of mass subversion. Curr Opin Microbiol 8: 28-34.

Dean-Nystrom EA, Gansheroff LJ, Mills M, Moon HW, O'Brien AD. 2002. Vaccination of pregnant dams with intimin(O157) protects suckling piglets from Escherichia coli O157:H7 infection. Infect Immun 70: 2414-2418.

Deng W, Li Y, Vallance BA, Finlay BB. 2001. Locus of enterocyte effacement from Citrobacter rodentium: Sequence analysis and evidence for horizontal transfer among attaching and effacing pathogens. Infect Immun 69: 6323-6335.

Deng W, Vallance BA, Li Y, Puente JL, Finlay BB. 2003. Citrobacter rodentium translocated intimin receptor (Tir) is an essential virulence factor needed for actin condensation, intestinal colonization and colonic hyperplasia in mice. Mol Microbiol 48: 95-115.

Deng W, Puente JL, Gruenheid S, Li Y, Vallance BA, Vázquez A, Barba J, Ibarra JA, O’Donnell P, Metalnikov P, et al. 2004. Dissecting virulence: Systematic and functional analyses of a pathogenicity island. Proc Natl Acad Sci 101: 3597-3602.

Deng W, de Hoog CL, Yu HB, Li Y, Croxen MA, Thomas NA, Puente JL, Foster LJ, Finlay BB. 2010. A comprehensive proteomic analysis of the type III secretome of Citrobacter rodentium. J Biol Chem 285: 6790-6800.

Deng W, Yu HB, de Hoog CL, Stoynov N, Li Y, Foster LJ, Finlay BB. 2012. Quantitative proteomic analysis of type III secretome of Enteropathogenic E. coli reveals an expanded effector repertoire for attaching/effacing bacterial pathogens. Mol Cell Proteomics 11: 692-709.

Dennis A, Kudo T, Kruidenier L, Girard F, Crepin VF, MacDonald TT, Frankel G, Wiles S. 2008. The p50 subunit of $\mathrm{NF}-\kappa \mathrm{B}$ is critical for in vivo clearance of the noninvasive enteric pathogen Citrobacter rodentium. Infect Immun 76: 4978-4988.

Dong N, Liu L, Shao F. 2010. A bacterial effector targets host DH-PH domain RhoGEFs and antagonizes macrophage phagocytosis. EMBO J 29: 1363-1376.

Donnenberg MS, Tacket CO, James SP, Losonsky G, Nataro JP, Wasserman SS, Kaper JB, Levine MM. 1993. Role of the eaeA gene in experimental enteropathogenic Escherichia coli infection. J Clin Invest 92: 1412-1417.

Eaton KA, Friedman DI, Francis GJ, Tyler JS, Young VB, Haeger J, Abu-Ali G, Whittam TS. 2008. Pathogenesis of renal disease due to enterohemorrhagic Escherichia coli in germ-free mice. Infect Immun 76: 3054-3063.

Eaton KA, Honkala A, Auchtung TA, Britton RA. 2011. Probiotic Lactobacillus reuteri ameliorates disease due to en- terohemorrhagic Escherichia coli in germfree mice. Infect Immun 79: 185-191.

Foubister V, Rosenshine I, Donnenberg MS, Finlay BB. 1994. The eaeB gene of enteropathogenic Escherichia coli is necessary for signal transduction in epithelial cells. Infect Immun 62: 3038-3040.

Frankel G, Phillips AD. 2008. Attaching effacing Escherichia coli and paradigms of Tir-triggered actin polymerization: Getting off the pedestal. Cell Microbiol 10: 549-556.

Frankel G, Phillips AD, Novakova M, Field H, Candy DC, Schauer DB, Douce G, Dougan G. 1996. Intimin from enteropathogenic Escherichia coli restores murine virulence to a Citrobacter rodentium eaeA mutant: Induction of an immunoglobulin A response to intimin and EspB. Infect Immun 64: 5315-5325.

Frankel G, Philips AD, Novakova M, Batchelor M, Hicks S, Dougan G. 1998a. Generation of Escherichia coli intimin derivatives with differing biological activities using sitedirected mutagenesis of the intimin C-terminus domain. Mol Microbiol 29: 559-570.

Frankel G, Phillips AD, Rosenshine I, Dougan G, Kaper JB, Knutton S. 1998b. Enteropathogenic and enterohaemorrhagic Escherichia coli: More subversive elements. Mol Microbiol 30: 911-921.

Ghaem-Maghami M, Simmons CP, Daniell S, Pizza M, Lewis D, Frankel G, Dougan G. 2001. Intimin-specific immune responses prevent bacterial colonization by the attaching-effacing pathogen Citrobacter rodentium. Infect Immun 69: 5597-5605.

Gibson DL, Ma C, Bergstrom KSB, Huang JT, Man C, Vallance BA. 2008. MyD88 signalling plays a critical role in host defence by controlling pathogen burden and promoting epithelial cell homeostasis during Citrobacter rodentium-induced colitis. Cell Microbiol 10: 618-631.

Girard F, Batisson I, Frankel GM, Harel J, Fairbrother JM. 2005. Interaction of enteropathogenic and Shiga toxinproducing Escherichia coli and porcine intestinal mucosa: Role of intimin and Tir in adherence. Infect Immun 73: 6005-6016.

Golan L, Gonen E, Yagel S, Rosenshine I, Shpigel NY. 2011. Enterohemorrhagic Escherichia coli induce attaching and effacing lesions and hemorrhagic colitis in human and bovine intestinal xenograft models. Dis Model Mech 4: 86-94.

Goosney DL, Celli J, Kenny B, Finlay BB. 1999. Enteropathogenic Escherichia coli inhibits phagocytosis. Infect Immun 67: 490-495.

Goosney DL, Gruenheid S, Finlay BB. 2000. Gut feelings: Enteropathogenic E. coli (EPEC) interactions with the host. Ann Rev Cell Dev Biol 16: 173-189.

Gruenheid S, DeVinney R, Bladt F, Goosney D, Gelkop S, Gish GD, Pawson T, Finlay BB. 2001. Enteropathogenic E. coli Tir binds Nck to initiate actin pedestal formation in host cells. Nat Cell Biol 3: 856-859.

Gruenheid S, Sekirov I, Thomas NA, Deng W, O’Donnell P, Goode D, Li Y, Frey EA, Brown NF, Metalnikov P, et al. 2004. Identification and characterization of NleA, a nonLEE-encoded type III translocated virulence factor of enterohaemorrhagic Escherichia coli O157:H7. Mol Microbiol 51: 1233-1249.

Hayashi T, Makino K, Ohnishi M, Kurokawa K, Ishii K, Yokoyama K, Han CG, Ohtsubo E, Nakayama K, 
R.J. Law et al.

Murata T, et al. 2001. Complete genome sequence of enterohemorrhagic Escherichia coli O157:H7 and genomic comparison with a laboratory strain K-12. DNA Res 8: $11-22$.

Hilbi H, Weber SS, Ragaz C, Nyfeler Y, Urwyler S. 2007. Environmental predators as models for bacterial pathogenesis. Environ Microbiol 9: 563-575.

Iguchi A, Thomson NR, Ogura Y, Saunders D, Ooka T, Henderson IR, Harris D, Asadulghani M, Kurokawa K, Dean P, et al. 2009. Complete genome sequence and comparative genome analysis of enteropathogenic Escherichia coli O127:H6 strain E2348/69. J Bacteriol 191: 347-354.

Inman LR, Cantey JR. 1983. Specific adherence of Escherichia coli (strain RDEC-1) to membranous (M) cells of the Peyer's patch in Escherichia coli diarrhea in the rabbit. J Clin Invest 71: 1-8.

Ivanov II, Atarashi K, Manel N, Brodie EL, Shima T, Karaoz U, Wei D, Goldfarb KC, Santee CA, Lynch SV, et al. 2009. Induction of intestinal Th17 cells by segmented filamentous bacteria. Cell 139: 485-498.

Jenkins C, Lawson AJ, Cheasty T, Willshaw GA, Wright P, Dougan G, Frankel G, Smith HR. 2003. Subtyping intimin genes from enteropathogenic Escherichia coli associated with outbreaks and sporadic cases in the United Kingdom and Eire. Mol Cell Probe 17: 149-156.

Kalman D, Weiner OD, Goosney DL, Sedat JW, Finlay BB, Abo A, Bishop JM. 1999. Enteropathogenic E. coli acts through WASP and Arp2 3 complex to form actin pedestals. Nat Cell Biol 1: 389-391.

Kaper JB, Nataro JP, Mobley HL. 2004. Pathogenic Escherichia coli. Nat Rev Microbiol 2: 123-140.

Kelly M, Hart E, Mundy R, Marchès O, Wiles S, Badea L, Luck S, Tauschek M, Frankel G, Robins-Browne RM, et al. 2006. Essential role of the type III secretion system effector NleB in colonization of mice by Citrobacter rodentium. Infect Immun 74: 2328-2337.

Kenny B. 2002. Mechanism of action of EPEC type III effector molecules. Int J Med Microbiol 291: 469-477.

Kenny B, DeVinney R, Stein M, Reinscheid DJ, Frey EA, Finlay BB. 1997. Enteropathogenic E. coli (EPEC) transfers its receptor for intimate adherence into mammalian cells. Cell 91: 511-520.

Klapproth JM, Sasaki M, Sherman M, Babbin B, Donnenberg MS, Fernandes PJ, Scaletsky ICA, Kalman D, Nusrat A, Williams IR. 2005. Citrobacter rodentium lifA/efal is essential for colonic colonization and crypt cell hyperplasia in vivo. Infect Immun 73: 1441-1451.

Knutton S, Lloyd DR, McNeish AS. 1987. Adhesion of enteropathogenic Escherichia coli to human intestinal enterocytes and cultured human intestinal mucosa. Infect Immun 55: 69-77.

Knutton S, Baldwin T, Williams PH, McNeish AS. 1989. Actin accumulation at sites of bacterial adhesion to tissue culture cells: Basis of a new diagnostic test for enteropathogenic and enterohemorrhagic Escherichia coli. Infect Immun 57: 1290-1298.

Kum WWS, Lo BC, Deng W, Ziltener HJ, Finlay BB. 2010. Impaired innate immune response and enhanced pathology during Citrobacter rodentium infection in mice lacking functional P-selectin. Cell Microbiol 12: 1250-1271.
Kurz CL, Ewbank JJ. 2000. Caenorhabditis elegans for the study of host-pathogen interactions. Trends Microbiol 8: $142-144$.

Kurz CL, Ewbank JJ. 2003. Caenorhabditis elegans: An emerging genetic model for the study of innate immunity. Nat Rev Genet 4: 380-390.

Larsen PL, Albert PS, Riddle DL. 1995. Genes that regulate both development and longevity in Caenorhabditis elegans. Genetics 139: 1567-1583.

Lebeis SL, Bommarius B, Parkos CA, Sherman MA, Kalman D. 2007. TLR signaling mediated by MyD88 is required for a protective innate immune response by neutrophils to Citrobacter rodentium. J Immunol 179: 566-577.

Luperchio SA, Schauer DB. 2001. Molecular pathogenesis of Citrobacter rodentium and transmissible murine colonic hyperplasia. Microbes Infect 3: 333-340.

MacDonald TT, Frankel G, Dougan G, Goncalves NS, Simmons C. 2003. Host defences to Citrobacter rodentium. Int J Med Microbiol 293: 87-93.

Marchès $O$, Nougayrède JP, Boullier S, Mainil J, Charlier G, Raymond I, Pohl P, Boury M, De Rycke J, Milon A, et al. 2000. Role of Tir and intimin in the virulence of rabbit enteropathogenic Escherichia coli serotype O103:H2. Infect Immun 68: 2171-2182.

Marchès $\mathrm{O}$, Covarelli V, Dahan $\mathrm{S}$, Cougoule $\mathrm{C}$, Bhatta $\mathrm{P}$, Frankel G, Caron E. 2008. EspJ of enteropathogenic and enterohaemorrhagic Escherichia coli inhibits opsono-phagocytosis. Cell Microbiol 10: 1104-1115.

Martinez-Argudo I, Sands C, Jepson MA. 2007. Translocation of enteropathogenic Escherichia coli across an in vitro $\mathrm{M}$ cell model is regulated by its type III secretion system. Cell Microbiol 9: 1538-1546.

McDaniel TK, Jarvis KG, Donnenberg MS, Kaper JB. 1995. A genetic locus of enterocyte effacement conserved among diverse enterobacterial pathogens. Proc Natl Acad Sci 92: 1664-1668.

McNamara BP, Koutsouris A, O'Connell CB, Nougayréde JP, Donnenberg MS, Hecht G. 2001. Translocated EspF protein from enteropathogenic Escherichia coli disrupts host intestinal barrier function. J Clin Invest 107: 621-629.

McNeilly TN, Mitchell MC, Rosser T, McAteer S, Low JC, Smith DGE, Huntley JF, Mahajan A, Gally DL. 2010 Immunization of cattle with a combination of purified intimin-531, EspA and Tir significantly reduces shedding of Escherichia coli O157:H7 following oral challenge. Vaccine 28: $1422-1428$.

Mellies JL, Barron AMS, Haack KR, Korson AS, Oldridge DA. 2006. The global regulator Ler is necessary for enteropathogenic Escherichia coli colonization of Caenorhabditis elegans. Infect Immun 74: 64-72.

Mills E, Baruch K, Charpentier X, Kobi S, Rosenshine I. 2008. Real-time analysis of effector translocation by the type III secretion system of enteropathogenic Escherichia coli. Cell Host Microbe 3: 104-113.

Misyurina O, Asper DJ, Deng W, Finlay BB, Rogan D, Potter AA. 2010. The role of Tir, EspA, and NleB in the colonization of cattle by Shiga toxin producing Escherichia coli O26:H11. Can J Microbiol 56: 739-747.

Miyamoto Y, Iimura M, Kaper JB, Torres AG, Kagnoff MF 2006. Role of Shiga toxin versus H7 flagellin in 
enterohaemorrhagic Escherichia coli signalling of human colon epithelium in vivo. Cell Microbiol 8: 869-879.

Mohawk KL, O’Brien AD. 2011. Mouse models of Escherichia coli $\mathrm{O} 157: \mathrm{H7}$ infection and shiga toxin injection. 2011. J Biomed Biotechnol 2011: 258185.

Mundy R, Petrovska L, Smollett K, Simpson N, Wilson RK, Yu J, Tu X, Rosenshine I, Clare S, Dougan G, et al. 2004. Identification of a novel Citrobacter rodentium type III secreted protein, EspI, and roles of this and other secreted proteins in infection. Infect Immun 72: 2288-2302.

Mundy R, Girard F, FitzGerald AJ, Frankel G. 2006. Comparison of colonization dynamics and pathology of mice infected with enteropathogenic Escherichia coli, enterohaemorrhagic E. coli and Citrobacter rodentium. FEMS Microbiol Lett 265: 126-132.

Mundy R, Schüller S, Girard F, Fairbrother JM, Phillips AD, Frankel G. 2007. Functional studies of intimin in vivo and ex vivo: Implications for host specificity and tissue tropism. Microbiology 153: 959-967.

Mylonakis E, Aballay A. 2005. Worms and flies as genetically tractable animal models to study host-pathogen interactions. Infect Immun 73: 3833-3841.

Nadler C, Baruch K, Kobi S, Mills E, Haviv G, Farago M, Alkalay I, Bartfeld S, Meyer TF, Ben-Neriah Y, et al. 2010. The type III secretion effector NleE inhibits NF-кB activation. PLoS Pathog 6: e1000743.

Nataro JP, Kaper JB. 1998. Diarrheagenic Escherichia coli. Clin Microbiol Rev 11: 142-201.

Newman JV, Zabel BA, Jha SS, Schauer DB. 1999. Citrobacter rodentium espB is necessary for signal transduction and for infection of laboratory mice. Infect Immun 67: 6019-6025.

Nieto-Pelegrin E, Martinez-Quiles N. 2009. Distinct phosphorylation requirements regulate cortactin activation by TirEPEC and its binding to N-WASP. Cell Commun Signal 7: 11.

Ogura $\mathrm{Y}$, Ooka T, Iguchi A, Toh $\mathrm{H}$, Asadulghani $\mathrm{M}$, Oshima K, Kodama T, Abe H, Nakayama K, Kurokawa K, et al. 2009. Comparative genomics reveal the mechanism of the parallel evolution of O157 and non-O157 enterohemorrhagic Escherichia coli. Proc Natl Acad Sci 106: 17939-17944.

Ota N, Wong K, Valdez P, Zheng Y, Crellin NK, Diehl L, Ouyang W. 2011. IL-22 bridges the lymphotoxin pathway with the maintenance of colonic lymphoid structures during infection with Citrobacter rodentium. Nat Immun 12: $941-948$.

Panos GZ, Betsi GI, Falagas ME. 2006. Systematic review: Are antibiotics detrimental or beneficial for the treat ment of patients with Escherichia coli O157:H7 infection? Aliment Pharmacol Ther 24: 731-742.

Perna NT, Plunkett G, Burland V, Mau B, Glasner JD, Rose DJ, Mayhew GF, Evans PS, Gregor J, Kirkpatrick HA, et al. 2001. Genome sequence of enterohaemorrhagic Escherichia coli O157:H7. Nature 409: 529-533.

Petty NK, Bulgin R, Crepin VF, Cerdeño-Tárraga AM, Schroeder GN, Quail MA, Lennard N, Corton C, Barron A, Clark L, et al. 2010. The Citrobacter rodentium genome sequence reveals convergent evolution with human pathogenic Escherichia coli. J Bacteriol 192: 525538.
Pflughoeft KJ, Versalovic J. 2011. Human microbiome in health and disease. Annu Rev Pathol 7: 99-122.

Potter AA, Klashinsky S, Li Y, Frey E, Townsend H, Rogan D, Erickson G, Hinkley S, Klopfenstein T, Moxley RA, et al. 2004. Decreased shedding of Escherichia coli O157:H7 by cattle following vaccination with type III secreted proteins. Vaccine 22: 362-369.

Quitard S, Dean P, Maresca M, Kenny B. 2006. The enteropathogenic Escherichia coli EspF effector molecule inhibits PI-3 kinase-mediated uptake independently of mitochondrial targeting. Cell Microbiol 8: 972-981.

Raymond B, Crepin VF, Collins JW, Frankel G. 2011. The WxxxE effector EspT triggers expression of immune mediators in an Erk/JNK and NF-kB-dependent manner. Cell Microbiol 13: 1881-1893.

Rhee KJ, Cheng H, Harris A, Morin C, Kaper JB, Hecht G. 2011. Determination of spatial and temporal colonization of enteropathogenic E. coli and enterohemorrhagic E. coli in mice using bioluminescent in vivo imaging. Gut Microbes 2: 34-41.

Robins-Browne RM, Tokhi AM, Adams LM, BennettWood V. 1994a. Host specificity of enteropathogenic Escherichia coli from rabbits: Lack of correlation between adherence in vitro and pathogenicity for laboratory animals. Infect Immun 62: 3329-3336.

Robins-Browne RM, Tokhi AM, Adams LM, BennettWood V, Moisidis AV, Krejany EO, O'Gorman LE 1994b. Adherence characteristics of attaching and effacing strains of Escherichia coli from rabbits. Infect Immun 62: 1584-1592.

Rosenshine I, Ruschkowski S, Stein M, Reinscheid DJ, Mills SD, Finlay BB. 1996. A pathogenic bacterium triggers epithelial signals to form a functional bacterial receptor that mediates actin pseudopod formation. EMBO J 15: 2613-2624.

Roxas JL, Koutsouris A, Bellmeyer A, Tesfay S, Royan S, Falzari K, Harris A, Cheng H, Rhee KJ, Hecht G. 2010. Enterohemorrhagic E. coli alters murine intestinal epithelial tight junction protein expression and barrier function in a Shiga toxin independent manner. Lab Invest 90: $1152-1168$.

Royan SV, Jones RM, Koutsouris A, Roxas JL, Falzari K, Weflen AW, Kim A, Bellmeyer A, Turner JR, Neish AS, et al. 2010. Enteropathogenic E. coli non-LEE encoded effectors $\mathrm{NleH} 1$ and $\mathrm{NleH} 2$ attenuate NF-кB activation. Mol Microbiol 78: 1232-1245.

Savkovic SD, Villanueva J, Turner JR, Matkowskyj KA, Hecht G. 2005. Mouse model of enteropathogenic Escherichia coli infection. Infect Immun 73: 1161-1170.

Scallan E, Hoekstra RM, Angulo FJ, Tauxe RV, Widdowson MA, Roy SL, Jones JL, Griffin PM. 2011. Foodborne illness acquired in the United States-Major pathogens. Emerg Infect Dis 17: 7-15.

Schauer DB, Falkow S. 1993. The eae gene of Citrobacter freundii biotype 4280 is necessary for colonization in transmissible murine colonic hyperplasia. Infect Immun 61: 4654-4661.

Schulenburg H, Kurz CL, Ewbank JJ. 2004. Evolution of the innate immune system: The worm perspective. Immunol Rev 198: 36-58.

Schüller S, Chong Y, Lewin J, Kenny B, Frankel G, Phillips AD. 2007. Tir phosphorylation and Nck/N-WASP 
R.J. Law et al.

recruitment by enteropathogenic and enterohaemorrhagic Escherichia coli during ex vivo colonization of human intestinal mucosa is different to cell culture models. Cell Microbiol 9: 1352-1364.

Schüller S, Lucas M, Kaper JB, Girón JA, Phillips AD. 2009. The ex vivo response of human intestinal mucosa to enteropathogenic Escherichia coli infection. Cell Microbiol 11: 521-530.

Sears CL. 2000. Molecular physiology and pathophysiology of tight junctions $\mathrm{V}$. assault of the tight junction by enteric pathogens. Am J Physiol Gastrointest Liver Physiol 279: G1129-G1134.

Sekirov I, Finlay BB. 2009. The role of the intestinal microbiota in enteric infection. J Physiol 587: 4159-4167.

Szabady RL, Lokuta MA, Walters KB, Huttenlocher A, Welch RA. 2009. Modulation of neutrophil function by a secreted mucinase of Escherichia coli O157:H7. PLoS Pathog 5: e1000320.

Tacket CO, Sztein MB, Losonsky G, Abe A, Finlay BB, McNamara BP, Fantry GT, James SP, Nataro JP, Levine MM, et al. 2000. Role of EspB in experimental human enteropathogenic Escherichia coli infection. Infect Immun 68: 3689-3695.

Takahashi M, Taguchi H, Yamaguchi H, Osaki T, Komatsu A, Kamiya S. 2004. The effect of probiotic treatment with Clostridium butyricum on enterohemorrhagic Escherichia coli O157:H7 infection in mice. FEMS Immunol Med Microbiol 41: 219-226.

Tan MW, Mahajan-Miklos S, Ausubel FM. 1999. Killing of Caenorhabditis elegans by Pseudomonas aeruginosa used to model mammalian bacterial pathogenesis. Proc Natl Acad Sci 96: 715-720.

Tarr PI, Gordon CA, Chandler WL. 2005. Shiga-toxin-producing Escherichia coli and haemolytic uraemic syndrome. Lancet 365: 1073-1086.

Tauschek M, Strugnell RA, Robins-Browne RM. 2002. Characterization and evidence of mobilization of the LEE pathogenicity island of rabbit-specific strains of enteropathogenic Escherichia coli. Mol Microbiol 44: 15331550.

Thanabalasuriar A, Koutsouris A, Weflen A, Mimee M, Hecht G, Gruenheid S. 2010. The bacterial virulence factor NleA is required for the disruption of intestinal tight junctions by enteropathogenic Escherichia coli. Cell Microbiol 12: 31-41.

Tobe T, Beatson SA, Taniguchi H, Abe H, Bailey CM, Fivian A, Younis R, Matthews S, Marches O, Frankel G, et al. 2006. An extensive repertoire of type III secretion effectors in Escherichia coli O157 and the role of lamb- doid phages in their dissemination. Proc Natil Acad Sci 103: 14941-14946.

Umanski T, Rosenshine I, Friedberg D. 2002. Thermoregulated expression of virulence genes in enteropathogenic Escherichia coli. Microbiology 148: 2735-2744.

Vallance BA, Deng W, Knodler LA, Finlay BB. 2002. Mice lacking Tand B lymphocytes develop transient colitis and crypt hyperplasia yet suffer impaired bacterial clearance during Citrobacter rodentium infection. Infect Immun 70: 2070-2081.

Vallance BA, Khan MA, Deng W, Gruenheid S, Finlay BB. 2004. Modeling enteropathogenic and enterohemorrhagic E. coli infections and disease. Drug Discovery Today 1: $73-79$.

Vossenkämper A, Marchès $\mathrm{O}$, Fairclough PD, Warnes G, Stagg AJ, Lindsay JO, Evans PC, Luong LA, Croft NM Naik S, et al. 2010. Inhibition of NF-кB signaling in human dendritic cells by the enteropathogenic Escherichia coli effector protein NleE. J Immunol 185: 41184127.

Wales AD, Woodward MJ, Pearson GR. 2005. Attachingeffacing bacteria in animals. J Comp Pathol 132: 1-26.

Wlodarska M, Willing B, Keeney KM, Menendez A, Bergstrom KS, Gill N, Russell SL, Vallance BA, Finlay BB 2011. Antibiotic treatment alters the colonic mucus layer and predisposes the host to exacerbated Citrobacter rodentium-induced colitis. Infect Immun 79: 1536-1545.

Wong ARC, Pearson JS, Bright MD, Munera D, Robinson KS, Lee SF, Frankel G, Hartland EL. 2011. Enteropathogenic and enterohaemorrhagic Escherichia coli: Even more subversive elements. Mol Microbiol 80: 14201438.

Zhang Q, Li Q, Wang C, Li N, Li J. 2010a. Redistribution of tight junction proteins during EPEC infection in vivo. Inflammation 35: 23-32.

Zhang Q, Li Q, Wang C, Liu X, Li N, Li J. 2010b. Enteropathogenic Escherichia coli changes distribution of occludin and ZO- 1 in tight junction membrane microdomains in vivo. Microb Pathogenesis 48: 28-34.

Zheng Y, Valdez PA, Danilenko DM, Hu Y, Sa SM, Gong Q, Abbas AR, Modrusan Z, Ghilardi N, de Sauvage FJ, et al. 2008. Interleukin- 22 mediates early host defense against attaching and effacing bacterial pathogens. Nat Med 14: 282-289.

Zhu C, Feng S, Thate TE, Kaper JB, Boedeker EC. 2006. Towards a vaccine for attaching/effacing Escherichia coli: A LEE encoded regulator (ler) mutant of rabbit enteropathogenic Escherichia coli is attenuated, immunogenic, and protects rabbits from lethal challenge with the wild-type virulent strain. Vaccine 24: 3845-3855. 


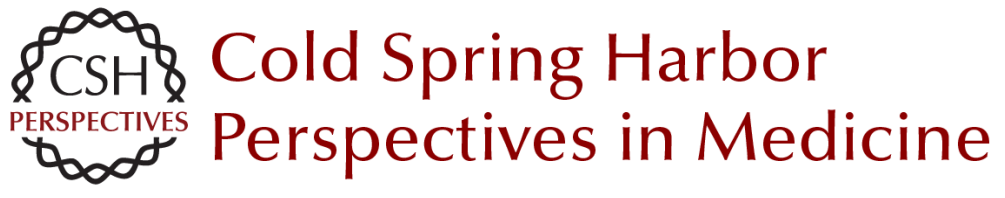

\title{
In Vitro and In Vivo Model Systems for Studying Enteropathogenic Escherichia coli Infections
}

\author{
Robyn J. Law, Lihi Gur-Arie, Ilan Rosenshine and B. Brett Finlay
}

Cold Spring Harb Perspect Med 2013; doi: 10.1101/cshperspect.a009977

\section{Subject Collection Bacterial Pathogenesis}

Therapeutic and Prophylactic Applications of

Bacteriophage Components in Modern Medicine Sankar Adhya, Carl R. Merril and Biswajit Biswas

Vaccines, Reverse Vaccinology, and Bacterial

Pathogenesis

Isabel Delany, Rino Rappuoli and Kate L. Seib

Helicobacter and Salmonella Persistent Infection

Strategies

Denise M. Monack

Echoes of a Distant Past: The cag Pathogenicity Island of Helicobacter pylori

Nicola Pacchiani, Stefano Censini, Ludovico Buti, et al.

RNA-Mediated Regulation in Pathogenic Bacteria Isabelle Caldelari, Yanjie Chao, Pascale Romby, et al.

The Pneumococcus: Epidemiology, Microbiology, and Pathogenesis

Birgitta Henriques-Normark and Elaine I.

Tuomanen

Pathogenesis of Meningococcemia

Mathieu Coureuil, Olivier Join-Lambert, Hervé

Lécuyer, et al.

Chlamydial Intracellular Survival Strategies

Robert J. Bastidas, Cherilyn A. Elwell, Joanne N.

Engel, et al.
Mechanisms and Biological Roles of

Contact-Dependent Growth Inhibition Systems

Christopher S. Hayes, Sanna Koskiniemi, Zachary

C. Ruhe, et al.

A Genome-Wide Perspective of Human Diversity and Its Implications in Infectious Disease Jérémy Manry and Lluis Quintana-Murci

Host Specificity of Bacterial Pathogens Andreas Bäumler and Ferric C. Fang

The Inside Story of Shigella Invasion of Intestinal Epithelial Cells

Nathalie Carayol and Guy Tran Van Nhieu

Bartonella and Brucella--Weapons and Strategies for Stealth Attack

Houchaima Ben-Tekaya, Jean-Pierre Gorvel and Christoph Dehio

Concepts and Mechanisms: Crossing Host

Barriers

Kelly S. Doran, Anirban Banerjee, Olivier Disson, et al.

Genome Dynamics in Legionella: The Basis of

Versatility and Adaptation to Intracellular

Replication

Laura Gomez-Valero and Carmen Buchrieser

Mechanisms of Francisella tularensis Intracellular

Pathogenesis

Jean Celli and Thomas C. Zahrt

For additional articles in this collection, see http://perspectivesinmedicine.cshlp.org/cgi/collection/ 